\title{
Gap-Junctional Coupling between Neurogliaform Cells and Various Interneuron Types in the Neocortex
}

\author{
Anna Simon, Szabolcs Oláh, Gábor Molnár, János Szabadics, and Gábor Tamás \\ Department of Comparative Physiology, University of Szeged, Szeged H-6726, Hungary
}

Electrical synapses contribute to the generation of synchronous activity in neuronal networks. Several types of cortical GABAergic neurons acting via postsynaptic $\mathrm{GABA}_{\mathrm{A}}$ receptors also form electrical synapses with interneurons of the same class, suggesting that synchronization through gap junctions could be limited to homogenous interneuron populations. Neurogliaform cells elicit combined $\mathrm{GABA}_{\mathrm{A}}$ and $\mathrm{GABA}_{\mathrm{B}}$ receptor-mediated postsynaptic responses in cortical pyramidal cells, but it is not clear whether neurogliaform cells are involved in networks linked by electrical coupling.

We recorded from pairs, triplets, and quadruplets of cortical neurons in layers 2 and 3 of rat somatosensory cortex (postnatal day $20-35$ ). Neurogliaform cells eliciting slow IPSPs on pyramidal cells also triggered divergent electrical coupling potentials on interneurons. Neurogliaform cells were electrically coupled to other neurogliaform cells, basket cells, regular-spiking nonpyramidal cells, to an axoaxonic cell, and to various unclassified interneurons showing diverse firing patterns and morphology. Electrical interactions were mediated by one or two electron microscopically verified gap junctions linking the somatodendritic domain of the coupled cells.

Our results suggest that neurogliaform cells have a unique position in the cortical circuit. Apart from eliciting combined $\mathrm{GABA}_{\mathrm{A}}$ and $\mathrm{GABA}_{\mathrm{B}}$ receptor-mediated inhibition on pyramidal cells, neurogliaform cells establish electrical synapses and link multiple networks formed by gap junctions restricted to a particular class of interneuron. Widespread electrical connections might enable neurogliaform cells to monitor the activity of different interneurons acting on $\mathrm{GABA}_{\mathrm{A}}$ receptors at various regions of target cells.

Key words: interneuron; gap junction; $\mathrm{GABA}_{\mathrm{B}}$ receptor; GABAergic neuron; basket cell; cerebral cortex

\section{Introduction}

Electrical coupling between neocortical interneurons is firmly established by anatomical studies and electrophysiological experiments (Galarreta and Hestrin, 2001; Bennett and Zukin, 2004; Connors and Long, 2004; Sohl et al., 2005). Dendrodendritic or dendrosomatic gap junctions or gap junction-like structures were shown between morphologically identified interneurons (Sloper, 1972; Tamas et al., 2000; Szabadics et al., 2001; Fukuda and Kosaka, 2003), and actual measurements of electrical coupling were performed between neighboring GABAergic interneurons (Galarreta and Hestrin, 1999; Gibson et al., 1999; Tamas et al., 2000; Venance et al., 2000; Szabadics et al., 2001; Blatow et al., 2003; Chu et al., 2003). Electrical coupling between neocortical interneurons appears to be highly specific: GABAergic neurons establish electrical coupling almost exclusively with interneurons of the same type forming several distinct networks linking homologous interneurons (Galarreta and Hestrin, 2001; Bennett and Zukin, 2004; Connors and Long, 2004).

The most prominent function demonstrated thus far for elec-

Received April 12, 2005; revised May 23, 2005; accepted May 23, 2005.

This work was supported by the Wellcome Trust, National Institutes of Health Grant NS35915, Nemzeti Kutatási és Technológiai Hivatal Grant RET008/2004, Országos Tudományos Kutatási Alapprogramok Grant T049535, and Boehringer Ingelheim Fonds. We thank É. Tóth for technical assistance.

Correspondence should be addressed to Gábor Tamás, Department of Comparative Physiology, University of Szeged, Közép fasor 52, Szeged H-6726, Hungary. E-mail: gtamas@bio.u-szeged.hu.

DOl:10.1523/JNEUROSCI.1431-05.2005

Copyright $\odot 2005$ Society for Neuroscience $\quad$ 0270-6474/05/256278-08\$15.00/0 trical coupling is the increased synchrony of firing between the coupled cells (Galarreta and Hestrin, 2001; Bennett and Zukin, 2004; Connors and Long, 2004). Synchronization within networks of particular interneurons is then propagated downstream in cortical microcircuits by the concerted action of GABAergic synapses entraining "postsynaptic" firing (Tamas et al., 2000; Szabadics et al., 2001; Blatow et al., 2003; Buhl et al., 2003). Several GABAergic cell types, homologously interconnected by gap junctions, are also effective in timing postsynaptic action potentials, suggesting that multiple pathways of synchronization operate in parallel within the cortical circuit (Cobb et al., 1995; Tamas et al., 2004). However, distinct cell types in neural circuits are known to establish electrical coupling and could perform special functions. For example, electrical coupling between rods and cones in the retina allows the summation of inputs to different cells and can improve resolution by reducing noise (Guldenagel et al., 2001; Demb and Pugh, 2002; Sohl et al., 2005). Sporadic evidence for heterologous electrical coupling in the neocortex shows coupling of spiny stellate cells and fast-spiking ( $\mathrm{fs}$ ) GABAergic interneurons and occasional coupling between different GABAergic cells (Venance et al., 2000; Chu et al., 2003), but the position of several known cortical cell types is not clear in gap-junctionally linked networks.

Neurogliaform (ngf) interneurons were first described by Ramon y Cajal (1904) as dwarf or spiderweb cells, referring to their compact dendritic tree and dense axonal arborization (Valverde, 1971; Jones, 1975; Kisvarday et al., 1990; Hestrin and 
Armstrong, 1996; Kawaguchi and Kubota, 1997). Neurogliaform cells have a thus far unique position among cortical interneurons, because they are capable of eliciting slow IPSPs in postsynaptic pyramidal cells through a combined recruitment of $\mathrm{GABA}_{\mathrm{A}}$ and $\mathrm{GABA}_{\mathrm{B}}$ receptors (Tamas et al., 2003). Here, we investigate the electrical synapses of this cell type and identify a multitude of interneuron types gap-junctionally coupled to neurogliaform cells using a combination of simultaneous patch-clamp recordings and correlated light and electron microscopy. Analysis of chemical synapses established by neurogliaform cells on various interneurons types requires a separate study.

\section{Materials and Methods}

Electrophysiology. All procedures were performed with the approval of the University of Szeged and in accordance with the National Institutes of Health Guide for the Care and Use of Laboratory Animals. Wistar rats (postnatal day 20-35) were anesthetized by the intraperitoneal injection of ketamine $(30 \mathrm{mg} / \mathrm{kg})$ and xylazine $(10 \mathrm{mg} / \mathrm{kg})$, and, after decapitation, coronal slices $(350 \mu \mathrm{m}$ thick) were prepared from the somatosensory cortex. Slices were incubated at room temperature for $1 \mathrm{~h}$ in a solution composed of (in mM) $130 \mathrm{NaCl}, 3.5 \mathrm{KCl}, 1 \mathrm{NaH}_{2} \mathrm{PO}_{4}, 24 \mathrm{NaHCO}_{3}$, $1 \mathrm{CaCl}, 3 \mathrm{MgSO}_{4}$, and $10 \mathrm{D}(+)$-glucose, saturated with $95 \% \mathrm{O}_{2}$ and $5 \%$ $\mathrm{CO}_{2}$. The solution used during recordings differed only in that it contained $3 \mathrm{~mm} \mathrm{CaCl}_{2}$ and $1.5 \mathrm{~mm} \mathrm{MgSO}$. Recordings were obtained at $\sim 35^{\circ} \mathrm{C}$ from up to four concomitantly recorded cells visualized in layer $2 / 3$ by infrared differential interference contrast videomicroscopy [Olympus (Tokyo, Japan) BX60WI microscope, Hamamatsu (Bridgewater, NJ) CCD camera, Luigs \& Neumann (Ratingen, Germany) infrapatch set-up, and two HEKA Elektronik (Lambrecht/Pfalz, Germany) EPC 10/double patch-clamp amplifiers]. Micropipettes (5-7 M $\Omega$ ) were filled with (in mM) $126 \mathrm{~K}$-gluconate, $4 \mathrm{KCl}, 4 \mathrm{ATP}-\mathrm{Mg}$, 0.3 GTP-NA 2,10 HEPES, 10 creatine phosphate, and 8 biocytin, pH 7.25, $300 \mathrm{mOsm}$. Signals were filtered at $5 \mathrm{kHz}$, digitized at $10 \mathrm{kHz}$, and analyzed with PULSE software (HEKA Elektronik). Presynaptic neurogliaform cells were stimulated to elicit action potentials with brief $(2 \mathrm{~ms})$ suprathreshold pulses at $>90 \mathrm{~s}$ intervals to avoid exhaustion of transmission; other cell types were stimulated at $0.1 \mathrm{~Hz}$. We applied the same paradigm throughout the study for consistency. Postsynaptic cells were held at $-51 \pm 4 \mathrm{mV}$ membrane potential. Unless specified, traces shown are averages of 30-200 episodes. The amplitude of postsynaptic events was defined as the difference between the peak amplitude and the baseline value measured before the postsynaptic potential onset. Data are given as mean \pm SD. Mann-Whitney $U$ test and Friedman test were used to compare datasets; differences were accepted as significant if $p \leq 0.05$.

Histology. Visualization of biocytin was performed as described previously (Tamas et al., 1997). Three-dimensional light microscopic reconstructions were performed using Neurolucida (MicroBrightField, Williston, VT) with $100 \times$ objective; dendrogram constructions and synaptic distance measurements were aided by Neuroexplorer (MicroBrightField) software. Dendrograms represent only the dendrites involved in the connections. Correlated light and electron microscopy were performed as described previously (Tamas et al., 1997; Szabadics et al., 2001).

\section{Results}

\section{Electrical coupling between neurogliaform cells}

Neurogliaform cells $(n=94)$ were identified during simultaneous dual, triple, and quadruple recordings of neurons in layer $2 / 3$ of rat somatosensory cortex based on their firing characteristics, followed by light microscopic evaluation of their dendritic and axonal morphology. Similarly to neurogliaform cells identified by previous studies (Hestrin and Armstrong, 1996; Kawaguchi and Kubota, 1997; Tamas et al., 2003), neurogliaform interneurons in our sample responded to long $(800 \mathrm{~ms})$, just above threshold current injections with late-spiking firing pattern (Figs. $1 A, 2 B$ ) (see Fig. $4 B$ ) or with an accelerating train of spikes (Figs. $1 A, 2 B, 3 B)$ when activated from resting membrane potential
A

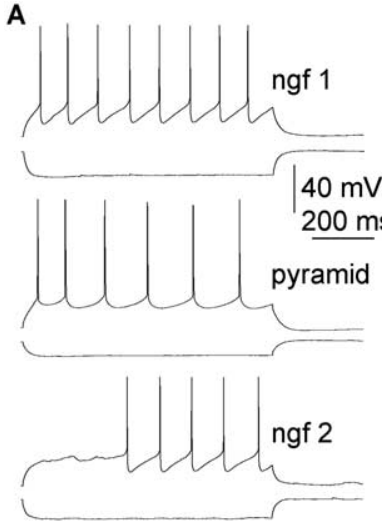

C

ngf 1 pre

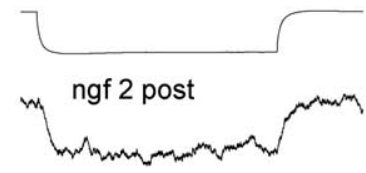

B

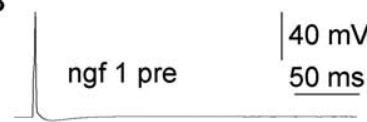

pyramid post

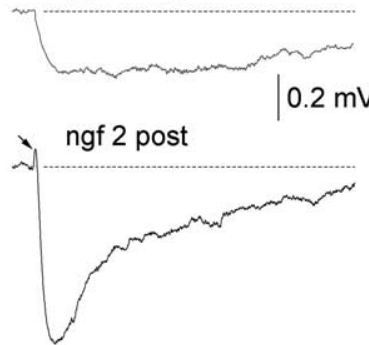

$15 \mathrm{mV}$

ngf 2 pre

$200 \mathrm{~ms}$

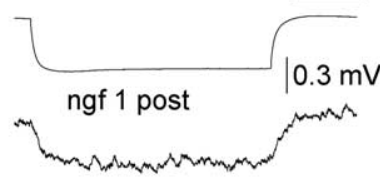

Figure 1. Neurogliaform cells eliciting slow IPSPs establish homologous electrical synapses. $A$, Firing pattern of two neurogliaform cells (ngf 1 and 2 ) and a pyramidal cell (pyramid) recorded in the same slice. $\boldsymbol{B}$, Single action potentials in the presynaptic neurogliaform cell (ngf 1) elicited a slow IPSP in the pyramidal cell and spikelet (arrow) followed by a long-lasting IPSP in the other neurogliaform cell. Note that the IPSPs do not return to baseline (dashed line) $250 \mathrm{~ms}$ after the presynaptic spike. C, Hyperpolarizing current injections into either neurogliaform cells were transmitted to the other cell, confirming electrical coupling. From the $16 \mathrm{ngf-ngf}$ cell connections tested, we confirmed electrical coupling in eight pairs (50\%). pre, Presynaptic; post, postsynaptic.

$(-64 \pm 3 \mathrm{mV})$. This firing behavior was changed to a decelerating pattern when applying larger current pulses (Fig. 2 B). All neurogliaform cells showed similar axonal features: small boutons frequently occurred along the thin axonal collaterals, forming a dense meshwork within the compact axonal field (Figs. 2-4).

When looking for connections to neurons closely located $(<100 \mu \mathrm{m})$ to the presynaptic neurogliaform cells, we sampled pyramidal cells as well as several types of interneuron. According to our previous studies showing strong frequency sensitivity of postsynaptic responses elicited by neurogliaform cells, we triggered single action potentials with an interval of $90 \mathrm{~s}$ to avoid the loss of responses. Simultaneous triple recordings showed that neurogliaform cells formed divergent connections, which were transmitted by electrical and chemical synapses (Fig. 1). Neurogliaform cells eliciting slow, presumably $\mathrm{GABA}_{\mathrm{A}}$ and $\mathrm{GABA}_{\mathrm{B}}$ receptor-mediated IPSPs on pyramidal neurons $(n=7)$ also triggered spikelets on other neurogliaform cells $(n=3)$ (Fig. 1) and other types of interneuron $(n=4)$, which could be followed by long-lasting IPSPs $(n=2$ on neurogliaform cells and $n=2$ on other interneurons). Electrical coupling indicated by spikelets in response to presynaptic action potentials was confirmed by the passage of hyperpolarizing signals between the coupled neurons (Fig. 1). These observations encouraged us to search for electrically coupled pairs of neurogliaform cells and interneurons representing various types.

Based on previous experiments showing widespread evidence for electrical coupling between similar GABAergic cells (Galarreta and Hestrin, 2001; Bennett and Zukin, 2004; Connors and Long, 2004), we proceeded by characterizing homologous electrical connections between neurogliaform cells. Of the 16 pairs of neighboring neurogliaform cells tested for electrical coupling, we 
confirmed electrical connections between neurogliaform cells in eight cases, indicating a $50 \%$ rate for coupling (Figs. 1,2). All electrical connections between ngf cells were reciprocal. Electrical coupling potentials in response to presynaptic spikes showed a relatively wide range in amplitude $(0.09-2.08 \mathrm{mV} ; 0.62 \pm 0.79 \mathrm{mV})$ at $-50 \pm 2 \mathrm{mV}$ membrane potential. They followed presynaptic action potentials with a delay of $0.34 \pm 0.19 \mathrm{~ms}$, measured as the period spanning the maximal rates of rise of the presynaptic action potential and the electrical coupling potential, respectively. The average amplitude ratio (coupling coefficient) for spikelets and presynaptic potentials was $0.17 \pm 0.06$ and $1.89 \pm 0.77 \%$ when eliciting action potentials and applying long current steps $(-200 \mathrm{pA}, 200 \mathrm{~ms}$ duration) in the first neuron to elicit a response in the second neuron, respectively. Coupling strength was similar in both directions and did not correlate with the distance between the recorded cell bodies $(39 \pm 13 \mu \mathrm{m})$. From the 16 presynaptic ngf cells, 11 triggered spikelets, which were followed by long-lasting IPSPs (Fig. $1 B$ ); these IPSPs will be characterized in a separate study. Three-dimensional light microscopic reconstruction and mapping of an electrically connected pair of neurogliaform cells indicated one close apposition between a proximal and a distal dendrite ( 4 and $57 \mu \mathrm{m}$ from the somata) (Fig. 2E), suggesting a single place for electrical communication.

\section{Gap-junctional coupling between neurogliaform and fast-spiking basket cells}

Apart from homologous electrical connections between ngf cells, we detected heterologous gap junctions linking ngf cells and fs cells. Fast-spiking basket cells were identified according to their firing characteristics followed by light microscopic evaluation of their dendritic and axonal morphology. Similarly to basket cells identified by previous studies (Tamas et al., 1997; Galarreta and Hestrin, 1999; Gibson et al., 1999; Gupta et al., 2000), fs basket interneurons responded to just above threshold current injections with "stuttering" groups of spikes (Figs. $2 B$ ) and with a nonaccomodating train of spikes when applying increased current steps (Fig. $2 B$ ). Membrane time constants of fs cells were also similar to values published previously (Kawaguchi, 1995; Tamas et al., 2003). All fs basket cells showed characteristic axonal branches frequently surrounding somata with large boutons relative to those of ngf cells (Fig. 2A). Electron microscopic sampling of postsynaptic targets of randomly selected fs cells $(n=3)$ confirmed the identity of these neurons as basket cells (Somogyi, 1989) showing a target preference toward somata $(28 \pm 5 \%)$ and

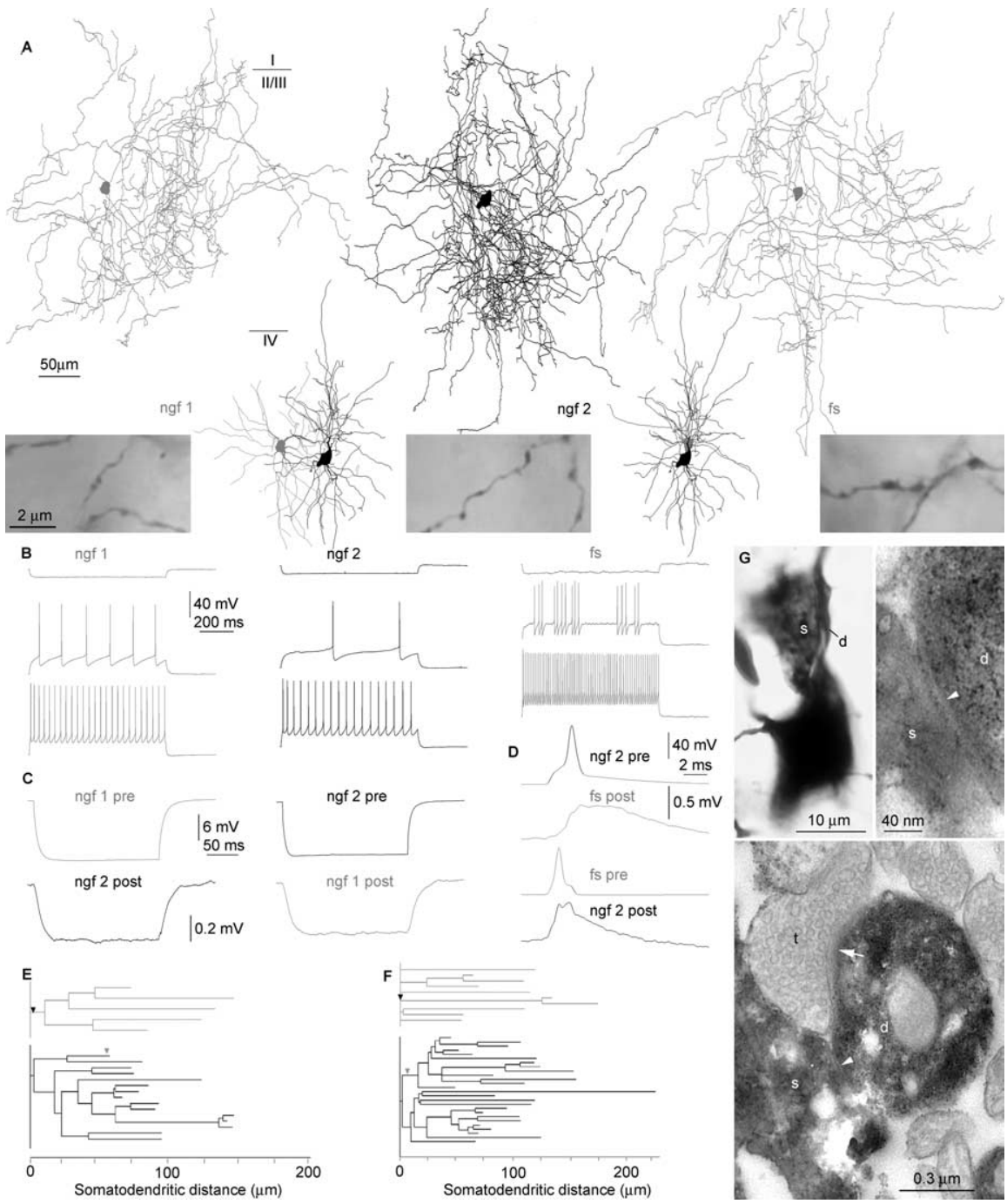

Figure 2. Heterologous gap junctions link the network of neurogliaform cells and fast-spiking basket cells. $\boldsymbol{A}$, Reconstructions of two neurogliaform cells (ngf 1, gray; ngf 2, black) and a fast-spiking basket cell (gray). Axonal and dendritic arborizations are shown separately for clarity. The position of cells is shown relative to the dendrites of ngf 2 , and the laminar position is shown relative to the axons. Light micrographs illustrate morphological differences between axon terminals. $\boldsymbol{B}$, Responses of the three cells to hyperpolarizing (top) and depolarizing current pulses (middle and bottom). C, Transmission of hyperpolarizing current injections into one of the cells confirmed electrical coupling between the neurogliaform cells. D. Action potentials elicited in coupling in six pairs (19\%). $\boldsymbol{E}, \boldsymbol{F}$, Dendrograms representing three-dimensional distances measured from the somata to the neurogliaform cell 2 and the fast-spiking cell. $\mathbf{G}$, Correlated light and electron microscopy identified a single gap junction as the site of interaction between the soma (s) of the fast-spiking cell and a proximal dendrite (d) of the neurogliaform cell 2. The dendrite of the neurogliaform cell also receives a synaptic junction (arrow) from an unidentified terminal ( $t$ ). pre, Presynaptic; post, postsynaptic.

dendritic shafts $(68 \pm 7 \%)$ and occasionally innervating dendritic spines $(3 \pm 3 \%)$.

From the 31 connections tested between closely spaced ngf and fs cells, we confirmed electrical coupling in six pairs, indicating a 19\% rate for interaction (Fig. 2). All electrical connections between ngf and fs cells were reciprocal, and, in three pairs, ngf cells elicited IPSPs on postsynaptic fs cells. Electrical coupling potentials in response to presynaptic spikes showed amplitudes of $0.52 \pm 0.23 \mathrm{mV}$ (range, $0.17-0.87 \mathrm{mV}$ ) at $-50 \pm 3 \mathrm{mV}$ membrane potential. The duration of electrical coupling potentials measured at half amplitude was longer in fs cells $(n=3)$ than in ngf $(n=6)$ cells $(9.11 \pm 2.95$ vs $3.80 \pm 1.23 \mathrm{~ms} ; p<0.02$; 


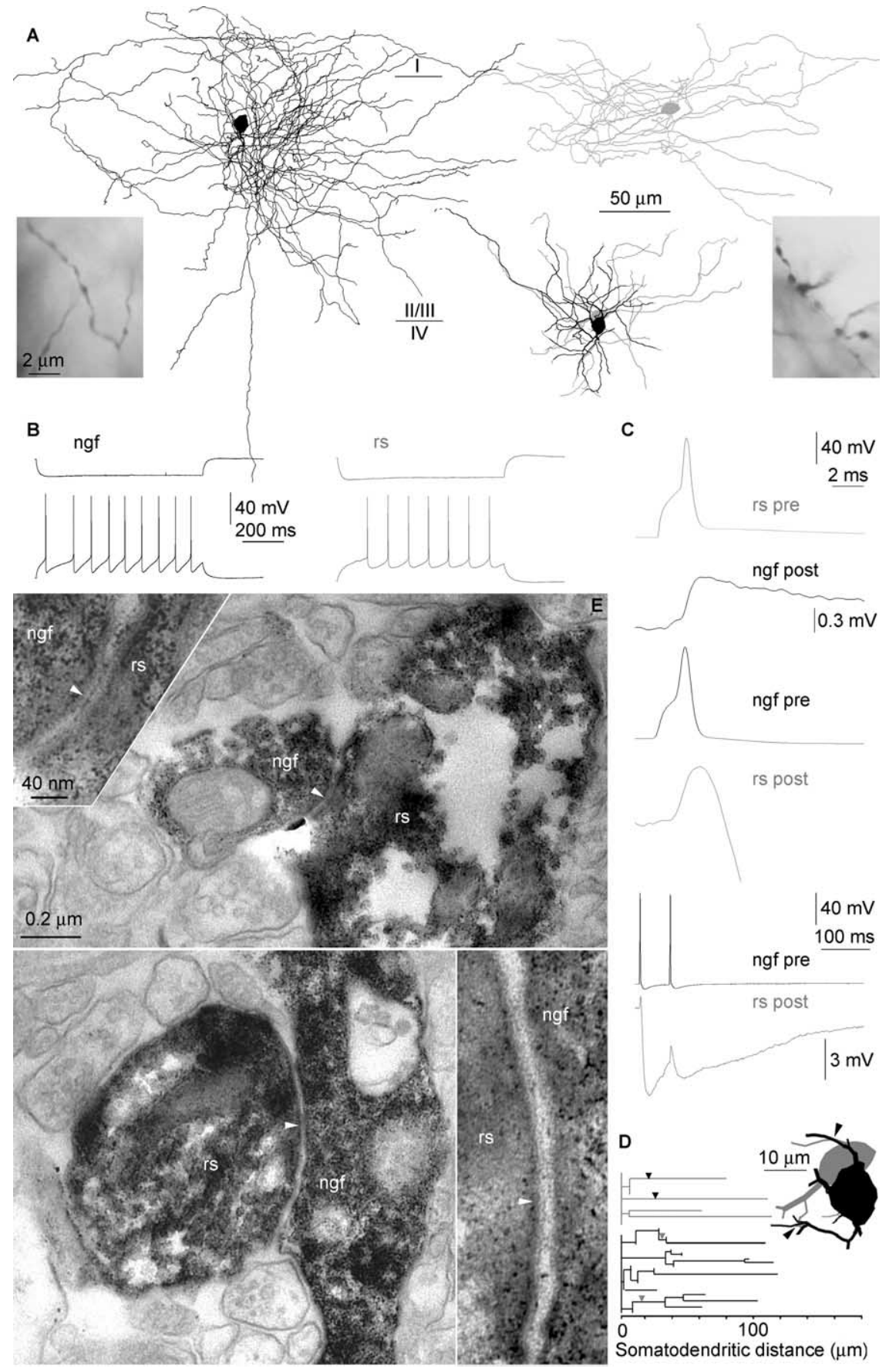

Figure 3. Heterologous gap junctions connect the network of neurogliaform cells with regular-spiking cells. $\boldsymbol{A}$, Reconstructions of the neurogliaform cell (black) and the regular-spiking cell (gray). Axonal and dendritic arborizations are shown separately for clarity. Dendritic reconstructions show the relative position of the cells. The laminar position is shown relative to the axons. Light micrographs illustrate morphological differences between axon terminals. $\boldsymbol{B}$, Responses of the cells to hyperpolarizing (top) and depolarizing current pulses (bottom). $\boldsymbol{C}$, Action potentials elicited in the regular-spiking cell elicited gap-junctional potentials or spikelets postsynaptically (top). Presynaptic spikes in the neurogliaform cell triggered a spikelet (middle) followed by a longlasting IPSP (bottom). Of the $30 \mathrm{ngf}-\mathrm{rs} \mathrm{cell} \mathrm{connections} \mathrm{tested,} \mathrm{we} \mathrm{confirmed} \mathrm{electrical} \mathrm{coupling} \mathrm{in} \mathrm{six} \mathrm{pairs} \mathrm{(20 \% ).} \mathrm{D,} \mathrm{Dendro-}$ grams representing three-dimensional distances measured from the somata to the gap junctions (arrowheads) mediating the interactions between the neurogliaform cell (black) and the regular-spiking cell (gray). Inset, The route of dendrites from the somata to the gap junctions (arrowheads). $\boldsymbol{E}$, Electron microscopic verification of the two gap junctions (arrowheads) between proximal dendrites of the ngf and rs cells. pre, Presynaptic; post, postsynaptic.

Mann-Whitney $U$ test), presumably because of the faster afterhyperpolarization in fs cells $(1.33 \pm 0.13$ vs $8.49 \pm 0.68 \mathrm{~ms}$, measured from the peak of action potential to the maximum of afterhyperpolarization). Spikelets followed presynaptic action potentials with a latency of $0.28 \pm 0.12 \mathrm{~ms}$. Amplitude ratios of presynaptic and postsynaptic potentials did not show direction selectivity. Coupling coefficients for spikelets and presynaptic potentials were $0.39 \pm 0.23$ and $3.76 \pm 1.42 \%$ when eliciting action potentials and applying long current steps in the first neuron to elicit a response in the second neuron, respectively. Thus, electrical coupling appears stronger in our limited sample of ng$\mathrm{f}-\mathrm{fs}$ than in ngf-ngf connections measured by transferring relatively long-lasting hyperpolarization ( $p<0.002$; Mann-Whitney $U$ test). The strength of coupling did not correlate with the distance measured between the somata of connected cells $(31 \pm 16 \mu \mathrm{m})$. Three-dimensional light microscopic reconstruction of two electrically connected ngf-fs pairs suggested one close apposition in each connection between the somata of the fs cells and proximal dendrites of the ngf cells ( 9 and 40.2 $\mu \mathrm{m}$ from the somata). Subsequent electron microscopy confirmed a single gap junction as the morphological correlate of electrical communication in both connections (Fig. $2 F-G$ ).

\section{Gap-junctional coupling between} neurogliaform and regular-spiking cells Finding heterologous gap junctions between ngf and basket cells propelled us to see whether ngf cells are electrically coupled to a multitude of interneuron types. We detected regular-spiking (rs) nonpyramidal cells as the second type of interneuron forming heterologous gap junctions with ngf cells. Similar to rs cells identified previously (Cauli et al., 1997; Kawaguchi and Kubota, 1997; Cauli et al., 2000; Szabadics et al., 2001; Tamas et al., 2004) they responded to suprathreshold current injections with a regular-spiking firing pattern (Fig. 3B). The morphology of sparsely spiny dendrites and individual axonal branches of all rs cells appeared similar showing undulating axon collaterals with relatively large, bead-like boutons (Fig. 3A). The overall axonal arborization of rs cells was restricted to a part of layer $2 / 3$ (Fig. $3 A$ ) or in addition to the arborization around the soma, rs cells sent a loose bundle of radially oriented branches toward layer 6 (Szabadics et al., 2001). Confirming previous results (Szabadics et al., 2001), electron microscopic samples of postsynaptic targets of randomly selected rs cells $(n=3)$ showed a target preference toward dendritic shafts $(53 \pm 13 \%)$ and dendritic spines $(47 \pm 13 \%)$ and did not target postsynaptic somata.

When testing connections between pairs $(n=30)$ of ngf and rs 


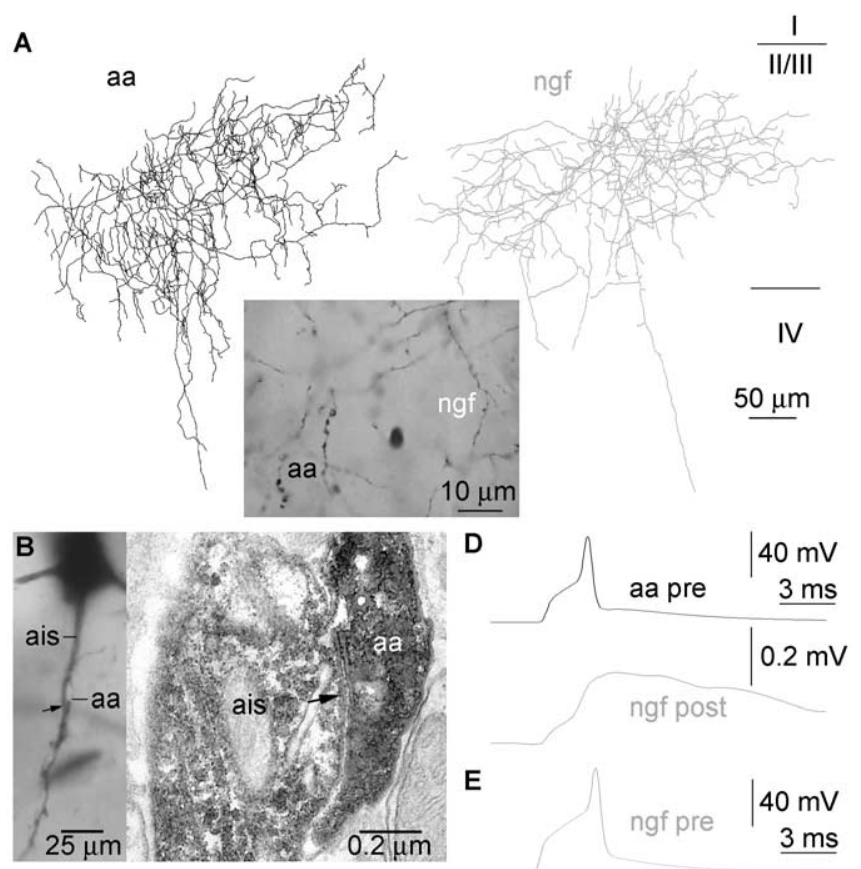

c

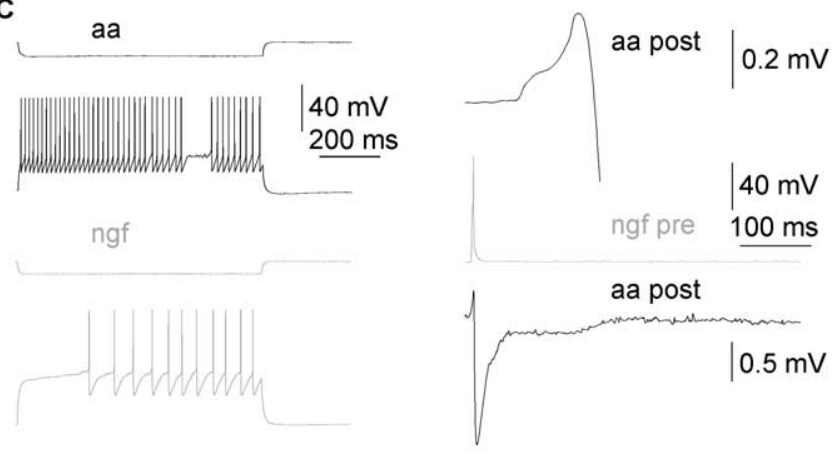

Figure 4. Heterologous electrical coupling between a neurogliaform cell and an axoaxonic cell. $\boldsymbol{A}$, Reconstructions of the ngf cell (gray) and the aa cell (black). Only axons were recovered from both cells. The light micrographs show morphological features of aa and ngf axon terminals. $\boldsymbol{B}$, Innervation of a pyramidal cell by the axoaxonic cell. Left, The axon of the axoaxonic cell (aa) forms a cartridge around the axon initial segment (ais) of the pyramidal cell. Right, Example of one of the five electron microscopically verified synaptic junctions (arrow) established by the axoaxonic cell on the axon initial segment of the pyramidal cell. $\boldsymbol{C}$, Responses of the cells to hyperpolarizing (top) and depolarizing current pulses (bottom). D, Action potentials elicited in the axoaxonic cell elicited gap-junctional potentials or spikelets postsynaptically. $\boldsymbol{E}$, Presynaptic spikes in the neurogliaform cell triggered a spikelet (top, expanded timescale) followed by an IPSP (bottom). pre, Presynaptic; post, postsynaptic.

nonpyramidal cells, we detected heterologous coupling in six cases, indicating a $20 \%$ rate for electrical synapses between these cell populations. All electrical connections between ngf and rs cells were mutual and all six ngf cells involved in electrical coupling elicited IPSPs on the postsynaptic rs cells. Electrical coupling potentials in response to presynaptic spikes showed amplitudes of $0.45 \pm 0.38 \mathrm{mV}$ (range, $0.18-0.72 \mathrm{mV}$ ) at $-50 \pm 3 \mathrm{mV}$ membrane potential. Spikelets followed presynaptic action potentials with a latency of $0.32 \pm 0.12 \mathrm{~ms}$. Electrical coupling strength was symmetrical between ngf and rs cells. Coupling coefficients for spikelets and presynaptic potentials were $1.01 \pm$ 0.60 and $4.59 \pm 3.98 \%$ when eliciting spikes and applying hyperpolarizing current steps in the first neuron to elicit a response in the second neuron, respectively. The strength of coupling was not correlated with the distance measured between the somata of connected interneurons $(28 \pm 19 \mu \mathrm{m})$. Three-dimensional light microscopic mapping and subsequent electron microscopy of an electrically connected ngf-rs pair determined two gap junctions mediating the interaction between proximal dendrites equidistant $(31.025 \pm 3.83 \mu \mathrm{m})$ from the somata (Fig. 3D-E).

\section{Neurogliaform cell-axoaxonic cell electrical coupling}

In search for electrically coupled partners for ngf cells, we recorded a single ngf cell-axoaxonic (aa) cell pair, and this cell pair was electrically coupled (Fig. 4). Although this was a single example, the unique output specificity of aa cells among cortical interneurons and the relatively limited number of aa cell connections studied thus far encouraged us to present the relevant data. Only the somata and axons were recovered from the cell pair, and we determined the identity of the aa cell based on the presence of characteristic cartridges or candles formed by axonal boutons (Szentagothai and Arbib, 1974; Somogyi, 1977) (Fig. 4A). Moreover, the aa cell innervated a pyramidal cell, which was also recorded in the same slice exclusively on the axon initial segment through five electron microscopically verified synaptic junctions (Fig. $4 B$ ). The aa cell had a firing pattern similar to fs cells (Fig. $4 B$ ). Electrical coupling between the aa and ngf cell was tested with presynaptic action potentials only; postsynaptic spikelets with onsets during the rising phase of presynaptic action potentials, the matching polarity of presynaptic and postsynaptic signals, and the reciprocity of connection ensured electrical coupling (Fig. 4C). The spikelet triggered by ngf cell was followed by an IPSP, which was not characterized pharmacologically (Fig. $4 D$ ).

\section{Electrical synapses between neurogliaform cells and other interneurons}

Electrical coupling between ngf and interneurons with firing properties and morphological characteristics distinct from ngf, fs, rs, and aa cells was tested in 26 pairs (data not shown). In 13 pairs, the interneurons recorded simultaneously with ngf cells responded to depolarizing current pulses with a so-called lowthreshold spiking firing pattern and showed dendritic and axonal features of bitufted (bt) cells (Gibson et al., 1999; Tamas et al., 2003, 2004). We identified two ngf-bt cell pairs and two ngf cell-unidentified interneuron pairs connected by electrical synapses, indicating an average coupling rate of $15 \%$. Apart from the spikelets evoked by the electrically coupled interneurons, an ngf cell elicited IPSPs in a bitufted cell, and an unidentified interneuron evoked an IPSP in an ngf cell (Fig. 5).

\section{Discussion}

We showed that ngf cells eliciting slow IPSPs on pyramidal cells also triggered divergent electrical coupling potentials on interneurons. In line with previous results showing widespread electrical coupling between interneurons of the same type, ngf cells formed homologous electrical synapses with other neurogliaform cells. The major point of this study is that ngf cells established heterologous electrical coupling with several types of interneuron. We also identified the sites of electrical interaction between different cell types and provided ultrastructural evidence for gap junctions linking somatodendritic sites of the coupled cells.

Our previous results on homologous electrical coupling between interneurons representing the same class identified the site of coupling ultrastructurally as gap junctions between the somata and/or dendrites of electrophysiologically recorded cells (Tamas et al., 2000; Szabadics et al., 2001). The possible axoaxonal elec- 


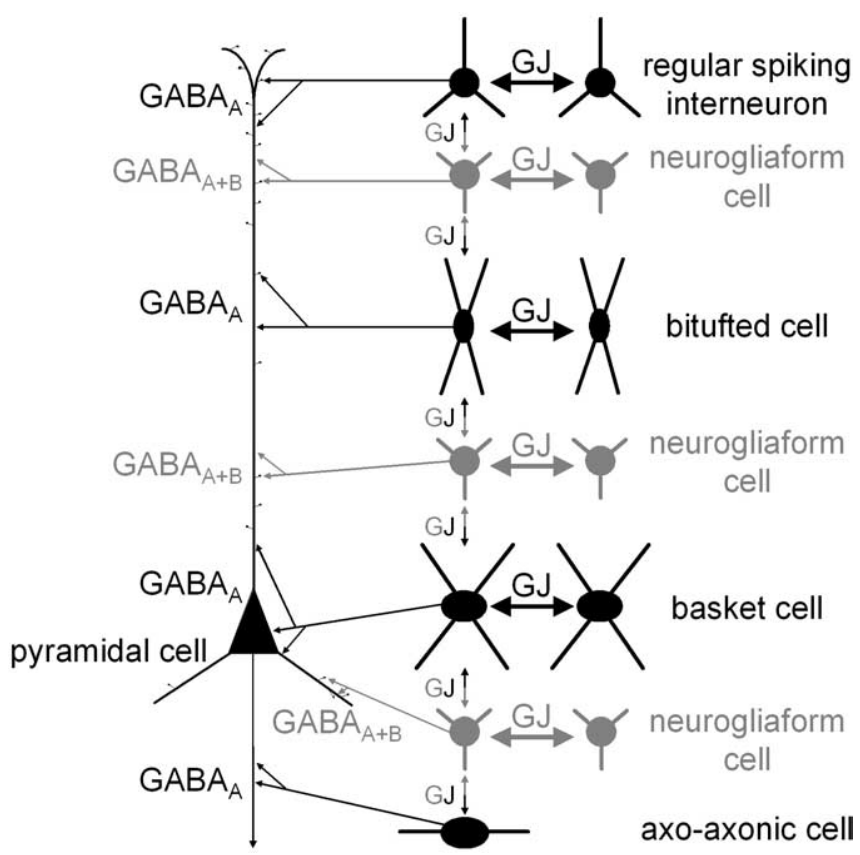

Figure 5. Neurogliaform cells have a unique position in the cortical microcircuit. To date, neurogliaform cells are the only interneuron type capable of eliciting slow $G A B A_{A}$ and $G A B A_{B}$ IPSPs on pyramidal cells. Several types of interneurons eliciting $G A B A_{A}$ receptor-mediated postsynaptic responses are known to form electrically coupled networks with interneurons of the same class. We found that neurogliaform cells are electrically coupled to other neurogliaform cells (gray), but, unlike other interneurons, neurogliaform cells also establish heterologous gap junctions (at a lower rate of coupling) with regular-spiking nonpyramidal cells, bitufted cells, basket cells, and axoaxonic cells. Thus, heterologous electrical synapses of neurogliaform cells link multiple networks formed by gap junctions restricted to a particular class of interneuron. Widespread electrical connections might enable neurogliaform cells to monitor the activity of different interneurons acting on $\mathrm{GABA}_{\mathrm{A}}$ receptors at various regions of target cells. GJ, Gap junction.

trical coupling between hippocampal pyramidal cells suggests that the formation of gap junctions could follow cell type or connection-specific subcellular patterns (Schmitz et al., 2001; Traub et al., 2003). However, heterologous electrical coupling identified here with combined recordings and electron microscopy also operates via somatodendritically placed gap junctions. Thus, it appears to be a generalized feature of cortical circuits that individual cells in electrically coupled networks of cortical interneurons are located within the dendritic arborization of each other and communicate through the dendrites. This could limit the size of electrically coupled networks, but the relatively uniform and moderate number of gap junctions identified within a single connection thus far allows the formation of widespread electrically interconnected circuits (Tamas et al., 2000; Deans et al., 2001; Szabadics et al., 2001). Ultrastructural identification of gap junctions between coupled cells recorded electrophysiologically also suggests that interneurons of the cerebral cortex are not coupled by cytoplasmic continuity, which can result from artifacts induced by slice cutting (Bennett and Zukin, 2004). This is also supported by previously documented absence of dye coupling between cortical interneurons known to form electrically coupled microcircuits (Galarreta and Hestrin, 2001; Bennett and Zukin, 2004; Connors and Long, 2004). The lack of dye coupling between interneurons of the same type and between ngf cells and other interneurons suggests that permeability properties and possibly the molecular composition of homologous and heterologous gap junctions of interneurons might be similar and involve connexin 36 (Venance et al., 2000). It should be added, however, that ngf cell-like dwarf neurons in the striatum of young rats can be dye coupled with neurons of different classes (Sancesario et al., 1998), but dye coupling may not be a reliable measure of gapjunction coupling among postnatal cortical neurons (Gutnick and Prince, 1981; Knowles et al., 1982; Connors et al., 1984; Roerig and Feller, 2000).

Several types of interneurons eliciting $\mathrm{GABA}_{\mathrm{A}}$ receptormediated postsynaptic responses are known to form electrically coupled networks with interneurons of the same class (Galarreta and Hestrin, 1999; Gibson et al., 1999; Tamas et al., 2000; Venance et al., 2000; Szabadics et al., 2001; Blatow et al., 2003; Chu et al., 2003; Bennett and Zukin, 2004). Fast IPSPs triggered by members of these networks are elicited on separate subcellular domains. It appears that the somatodendritic domain of postsynaptic cells is targeted by several separate networks of basket or basket-like cells intrinsically linked by gap junctions (Galarreta and Hestrin, 1999; Gibson et al., 1999; Tamas et al., 2000). Similarly, the dendritic region of postsynaptic neurons also receives a multitude of inputs from a number cell populations (rs cells, bitufted or low-threshold spiking cells, and layer 1 interneurons) which were shown to form electrical synapses restricted to the same type of interneuron (Gibson et al., 1999; Venance et al., 2000; Szabadics et al., 2001; Chu et al., 2003). Despite targeting the dendritic domain of postsynaptic neurons and forming electrical synapses within the cell class, ngf cells could have an exceptional position in the cortical architecture. From the multitude of cortical GABAergic interneurons, ngf cells represent the first cell type capable of eliciting slow IPSPs composed of $\mathrm{GABA}_{\mathrm{A}}$ and $\mathrm{GABA}_{\mathrm{B}}$ receptor-mediated postsynaptic responses with single presynaptic spikes (Tamas et al., 2003). Moreover, neurogliaform cells establish electrical synapses and link multiple networks formed by gap junctions restricted to a particular class of interneuron.

In-depth analysis of the function of electrical synapses established by ngf cells awaits additional experiments. Homologous electrical synapses within a multitude of cell populations were found to promote synchronization of the coupled cells (Hestrin and Armstrong, 1996; Bennett and Zukin, 2004; Connors and Long, 2004; Sohl et al., 2005). Unlike other known types of interneuron, ngf cells elicit $\mathrm{GABA}_{\mathrm{A}}$ and $\mathrm{GABA}_{\mathrm{B}}$ receptor-mediated postsynaptic potentials on pyramidal cells (Tamas et al., 2003) and synchronous release of GABA from several presynaptic interneurons was suggested to be involved in the activation of postsynaptic $\mathrm{GABA}_{\mathrm{B}}$ receptors (Mody et al., 1994; Kim et al., 1997; Thomson and Destexhe, 1999). Although single spikes in ngf cells are sufficient for eliciting the $\mathrm{GABA}_{\mathrm{B}}$ receptor-mediated response, we did not detect spike transmission through gap junctions linking ngf cells, in agreement with previous reports showing that synchronization is promoted by electrical coupling but is usually too weak for spike-to-spike coupling (Tamas et al., 1997; Galarreta and Hestrin, 1999; Gibson et al., 1999; Szabadics et al., 2001; Blatow et al., 2003). However, unlike other known networks of electrically coupled interneurons, ngf cells are embedded into a widespread mesh of electrical synapses linking multiple interneuron classes. Our results suggest that ngf cells form electrical connections with one-half of the neurogliaform cells and with every fifth interneuron representing at least three distinct types within the range of their relatively compact dendritic field. The strength of coupling is similar in homologous and heterologous electrical synapses established by ngf cells and is comparable with values published previously for homologous coupling in networks of other interneurons (Galarreta and Hestrin, 
1999; Gibson et al., 1999). Whether heterologous electrical coupling of neurogliaform cells has a specific function similar to retinal gap junctions between dissimilar components of the circuit remains to be seen (Guldenagel et al., 2001; Demb and Pugh, 2002; Lee et al., 2003; Hornstein et al., 2004; Sohl et al., 2005). Theoretical studies suggest that electrical synapses could stabilize synchronization by compensating network heterogeneity (Sherman and Rinzel, 1992; Chow and Kopell, 2000; Kopell and Ermentrout, 2004). Thus, it is conceivable that heterologous coupling between ngf cells and other interneuron types could contribute to operational state-dependent and simultaneous recruitment of ngf cells, which can boost their efficacy in reaching $\mathrm{GABA}_{\mathrm{B}}$ receptors. In contrast, widespread homologous and heterologous electrical coupling counteracts the spike-triggering effectiveness of excitatory inputs arriving to ngf cells by siphoning current into coupled cells. It was estimated that approximately one-third to one-half of input conductance of neurons involved in electrical coupling occurs via gap junctions to neighboring cells (Amitai et al., 2002; Long et al., 2002). Such postsynaptic conductance load could contribute to the late-spiking firing characteristics of ngf cells and might regulate firing behavior during network operations favoring sporadic and delayed firing of ngf neurons paralleled by the prominent frequency sensitivity of ngf output (Tamas et al., 2003). Thus, neurogliaform cells eliciting slow IPSPs and forming homologous and heterologous gapjunctional connections appear well positioned to monitor the activity of different interneurons acting on $\mathrm{GABA}_{\mathrm{A}}$ receptors at various regions of target cells.

\section{References}

Amitai Y, Gibson JR, Beierlein M, Patrick SL, Ho AM, Connors BW, Golomb D (2002) The spatial dimensions of electrically coupled networks of interneurons in the neocortex. J Neurosci 22:4142-4152.

Bennett MV, Zukin RS (2004) Electrical coupling and neuronal synchronization in the mammalian brain. Neuron 41:495-511.

Blatow M, Rozov A, Katona I, Hormuzdi SG, Meyer AH, Whittington MA, Caputi A, Monyer H (2003) A novel network of multipolar bursting interneurons generates theta frequency oscillations in neocortex. Neuron $38: 805-817$.

Buhl DL, Harris KD, Hormuzdi SG, Monyer H, Buzsaki G (2003) Selective impairment of hippocampal $\gamma$ oscillations in connexin-36 knock-out mouse in vivo. J Neurosci 23:1013-1018.

Cauli B, Audinat E, Lambolez B, Angulo MC, Ropert N, Tsuzuki K, Hestrin S, Rossier J (1997) Molecular and physiological diversity of cortical nonpyramidal cells. J Neurosci 17:3894-3906.

Cauli B, Porter JT, Tsuzuki K, Lambolez B, Rossier J, Quenet B, Audinat E (2000) Classification of fusiform neocortical interneurons based on unsupervised clustering. Proc Natl Acad Sci USA 97:6144-6149.

Chow CC, Kopell N (2000) Dynamics of spiking neurons with electrical coupling. Neural Comput 12:1643-1678.

Chu Z, Galarreta M, Hestrin S (2003) Synaptic interactions of late-spiking neocortical neurons in layer 1. J Neurosci 23:96-102.

Cobb SR, Buhl EH, Halasy K, Paulsen O, Somogyi P (1995) Synchronization of neuronal activity in hippocampus by individual GABAergic interneurons. Nature 378:75-78.

Connors BW, Long MA (2004) Electrical synapses in the mammalian brain. Annu Rev Neurosci 27:393-418.

Connors BW, Benardo LS, Prince DA (1984) Carbon dioxide sensitivity of dye coupling among glia and neurons of the neocortex. J Neurosci 4:1324-1330.

Deans MR, Gibson JR, Sellitto C, Connors BW, Paul DL (2001) Synchronous activity of inhibitory networks in neocortex requires electrical synapses containing connexin 36. Neuron 31:477-485.

Demb JB, Pugh EN (2002) Connexin36 forms synapses essential for night vision. Neuron 36:551-553.

Fukuda T, Kosaka T (2003) Ultrastructural study of gap junctions between dendrites of parvalbumin-containing GABAergic neurons in various neocortical areas of the adult rat. Neuroscience 120:5-20.
Galarreta M, Hestrin S (1999) A network of fast-spiking cells in the neocortex connected by electrical synapses. Nature 402:72-75.

Galarreta M, Hestrin S (2001) Electrical synapses between GABA-releasing interneurons. Nat Rev Neurosci 2:425-433.

Gibson JF, Beierlein M, Connors BW (1999) Two networks of electrically coupled inhibitory neurons in neocortex. Nature 402:75-79.

Guldenagel M, Ammermuller J, Feigenspan A, Teubner B, Degen J, Sohl G, Willecke K, Weiler R (2001) Visual transmission deficits in mice with targeted disruption of the gap junction gene connexin36. J Neurosci 21:6036-6044.

Gupta A, Wang Y, Markram H (2000) Organizing principles for a diversity of GABAergic interneurons and synapses in the neocortex. Science 287:273-278.

Gutnick MJ, Prince DA (1981) Dye coupling and possible electrotonic coupling in the guinea pig neocortical slice. Science 211:67-70.

Hestrin S, Armstrong WE (1996) Morphology and physiology of cortical neurons in layer I. J Neurosci 16:5290-5300.

Hornstein EP, Verweij J, Schnapf JL (2004) Electrical coupling between red and green cones in primate retina. Nat Neurosci 7:745-750.

Jones EG (1975) Varieties and distribution of non-pyramidal cells in the somatic sensory cortex of the squirrel monkey. J Comp Neurol 160:205-268.

Kawaguchi Y (1995) Physiological subgroups of nonpyramidal cells with specific morphological characteristics in layer II/III of rat frontal cortex. J Neurosci 15:2638-2655.

Kawaguchi Y, Kubota Y (1997) GABAergic cell subtypes and their synaptic connections in rat frontal cortex. Cereb Cortex 7:476-486.

Kim U, Sanchez-Vives MV, McCormick DA (1997) Functional dynamics of GABAergic inhibition in the thalamus. Science 278:130-134.

Kisvarday ZF, Gulyas A, Beroukas D, North JB, Chubb IW, Somogyi P (1990) Synapses, axonal and dendritic patterns of GABAimmunoreactive neurons in human cerebral cortex. Brain 113:793-812.

Knowles WD, Funch PG, Schwartzkroin PA (1982) Electrotonic and dye coupling in hippocampal CA1 pyramidal cells in vitro. Neuroscience 7:1713-1722.

Kopell N, Ermentrout B (2004) Chemical and electrical synapses perform complementary roles in the synchronization of interneuronal networks. Proc Natl Acad Sci USA 101:15482-15487.

Lee EJ, Han JW, Kim HJ, Kim IB, Lee MY, Oh SJ, Chung JW, Chun MH (2003) The immunocytochemical localization of connexin 36 at rod and cone gap junctions in the guinea pig retina. Eur J Neurosci 18:2925-2934.

Long MA, Deans MR, Paul DL, Connors BW (2002) Rhythmicity without synchrony in the electrically uncoupled inferior olive. J Neurosci 22:10898-10905.

Mody I, De Koninck Y, Otis TS, Soltesz I (1994) Bridging the cleft at GABA synapses in the brain. Trends Neurosci 17:517-525.

Ramon y Cajal S (1904) Textura del systema nervioso del hombre y los vertebrados. Madrid: Imprenta y Librería de Nicolás Moya.

Roerig B, Feller MB (2000) Neurotransmitters and gap junctions in developing neural circuits. Brain Res Brain Res Rev 32:86-114.

Sancesario G, Pisani A, D’Angelo V, Calabresi P, Bernardi G (1998) Morphological and functional study of dwarf neurons in the rat striatum. Eur J Neurosci 10:3575-3583.

Schmitz D, Schuchmann S, Fisahn A, Draguhn A, Buhl EH, Petrasch-Parwez E, Dermietzel R, Heinemann U, Traub RD (2001) Axo-axonal coupling. A novel mechanism for ultrafast neuronal communication. Neuron 31:831-840.

Sherman A, Rinzel J (1992) Rhythmogenic effects of weak electrotonic coupling in neuronal models. Proc Natl Acad Sci USA 89:2471-2474.

Sloper JJ (1972) Gap junctions between dendrites in the primate neocortex. Brain Res 44:641-646.

Sohl G, Maxeiner S, Willecke K (2005) Expression and functions of neuronal gap junctions. Nat Rev Neurosci 6:191-200.

Somogyi P (1977) A specific 'axo-axonal' interneuron in the visual cortex of the rat. Brain Res 136:345-350.

Somogyi P (1989) Synaptic organisation of GABAergic neurons and GABAA receptors in the lateral geniculate nucleus and visual cortex. In: Neural mechanisms of visual perception (Lam DK-T, Gilbert CD, eds), pp 35-62. Houston: Portfolio. 
Szabadics J, Lorincz A, Tamas G (2001) $\beta$ and $\gamma$ frequency synchronizationby dendritic GABAergic synapses and gap junctions in a network of cortical interneurons. J Neurosci 21:5824-5831.

Szentagothai J, Arbib MA (1974) Conceptual models of neural organization. Neurosci Res Prog Bull 12:305-510.

Tamas G, Buhl EH, Somogyi P (1997) Fast IPSPs elicited via multiple synaptic release sites by distinct types of GABAergic neuron in the cat visual cortex. J Physiol (Lond) 500:715-738.

Tamas G, Buhl EH, Lorincz A, Somogyi P (2000) Proximally targeted GABAergic synapses and gap junctions synchronize cortical interneurons. Nat Neurosci 3:366-371.

Tamas G, Lorincz A, Simon A, Szabadics J (2003) Identified sources and targets of slow inhibition in the neocortex. Science 299:1902-1905.

Tamas G, Szabadics J, Lorincz A, Somogyi P (2004) Input and frequency- -specific entrainment of postsynaptic firing by IPSPs of perisomatic or dendritic origin. Eur J Neurosci 20:2681-2690.

Thomson AM, Destexhe A (1999) Dual intracellular recordings and computational models of slow inhibitory postsynaptic potentials in rat neocortical and hippocampal slices. Neuroscience 92:1193-1215.

Traub RD, Pais I, Bibbig A, LeBeau FE, Buhl EH, Hormuzdi SG, Monyer H, Whittington MA (2003) Contrasting roles of axonal (pyramidal cell) and dendritic (interneuron) electrical coupling in the generation of neuronal network oscillations. Proc Natl Acad Sci USA 100:1370-1374.

Valverde F (1971) Short axon neuronal subsystems in the visual cortex of the monkey. Int J Neurosci 1:181-197.

Venance L, Rozov A, Blatow M, Burnashev N, Feldmeyer D, Monyer H (2000) Connexin expression in electrically coupled postnatal rat brain neurons. Proc Natl Acad Sci USA 97:10260-10265. 